Article

\title{
Impact of Management Tools Supporting Industry 4.0 on the Importance of CSR during COVID-19. Generation Z
}

\author{
Szymon Cyfert ${ }^{1, * \mathbb{D}}$, Waldemar Glabiszewski ${ }^{2}$ and Maciej Zastempowski ${ }^{2}$ D \\ 1 Institute of Management, Poznan University of Economics and Business, al. Niepodległosci 10, \\ 61-875 Poznan, Poland \\ 2 Faculty of Economic Sciences and Management, Nicolaus Copernicus University in Torun, ul. Gagarina 13a, \\ 87-100 Torun, Poland; waldemar.glabiszewski@umk.pl (W.G.); mz@umk.pl (M.Z.) \\ * Correspondence: s.cyfert@ue.poznan.pl
}

check for updates

Citation: Cyfert, S.; Glabiszewski, W.; Zastempowski, M. Impact of Management Tools Supporting Industry 4.0 on the Importance of CSR during COVID-19. Generation Z. Energies 2021, 14, 1642. https:// doi.org/10.3390/en14061642

Academic Editor: Patrycja Hąbek

Received: 10 February 2021

Accepted: 11 March 2021

Published: 16 March 2021

Publisher's Note: MDPI stays neutral with regard to jurisdictional claims in published maps and institutional affiliations.

Copyright: (c) 2021 by the authors. Licensee MDPI, Basel, Switzerland. This article is an open access article distributed under the terms and conditions of the Creative Commons Attribution (CC BY) license (https:// creativecommons.org/licenses/by/ $4.0 /)$.

\begin{abstract}
Taking into account the impact of the COVID-19 and adopting the assessment optics of students from Generation $\mathrm{Z}$ currently entering the labor market, we have made the aim of this article to provide better insight into the relationship between Industry 4.0 and corporate social responsibility. The survey was conducted in the form of an online survey in two leading universities in Poland in the field of economic education. 646 students took part in the survey. The data were analyzed using logit regression models. The results of the study suggest that the increase in the use of management solutions supporting Industry 4.0 in the wake of the COVID-19 crisis will increase the importance of the economic, social, and environmental dimensions of corporate social responsibility. Pointing to the forecasted increase importance of corporate social responsibility, we suggest linking management solutions supporting Industry 4.0 with corporate social responsibility. However, we also draw attention to the impact of individual management solutions supporting Industry 4.0 on specific Corporate Social Responsibility (CSR) dimensions.
\end{abstract}

Keywords: CSR; management tools; Industry 4.0; COVID-19; Gen Z

\section{Introduction}

The observed increase in awareness of shared responsibility for solving social and consumer problems, affecting the change in attitudes of customers' preferences and the way enterprises operate, is reflected in the growing interest in the CSR concept, which has lasted for over a decade [1]. Izzo and Ciaburri indicate that the reasons for the growing interest in CSR should be sought both in the pressure on firms' behavior arising from the social community and environmental constraints and the need to justify the investments firms underpin, even in critical and crisis periods [2]. Commitment to CSR is particularly evident among Generation Y and Generation Z consumers, who are willing to support socially responsible businesses through purchasing decisions, expressions of opinion, or involvement in volunteering [3,4]. However, while the implementation of CSR initiatives in an economically prosperous environment does not raise major questions, research suggests that in crisis situations, due to poor financial performance, enterprises are willing to reduce their investments in socially responsible initiatives [5].

The increase in the dynamics of the environment and the high variability of customer requirements force companies to evolve towards solutions based on the assumptions of Industry 4.0, which, together with the underlying digital transformation, fundamentally change the way of living and working [6]; however the transformation towards Industry 4.0 faces many problems due to inadequate information technology, lack of knowledge and high investment costs [7]. Fatorachian \& Kazemi [8] suggest that the use of the capabilities of Industry 4.0 in the production process requires recourse to new business models and operational structures that provide a high level of integration and connectivity 
between machines and production and corporate systems and justify the need to support the activities of Industry 4.0 with management science solutions.

Although corporate social responsibility is a phenomenon widely described in the management literature, and the issue of Industry 4.0 has been the subject of numerous practical studies, there is still a lack of clarity about the relationship between CSR and Industry 4.0 [9-11]. Moreover, in the current conditions, an important question arises, from the perspective of the concept of social responsibility, whether the crisis caused by COVID19 will increase the importance of actions implemented in corporate social responsibility. Taking into account the impact of COVID-19 and adopting the assessment optics of students from Generation $\mathrm{Z}$ currently entering the labor market, we have made the aim of this article to provide a better insight into the relationship between Industry 4.0 and corporate social responsibility, and in particular we have attempted to answer the following two questions (1) which management solutions supporting Industry 4.0 will increase the importance of the economic, social, and environmental dimension of corporate social responsibility; (2) which management solutions supporting Industry 4.0 will increase the importance of the economic, social, and environmental dimension of corporate social responsibility.

The study was conducted on a group of 646 economics, finance and management students with well-established knowledge of management science and corporate social responsibility in management processes, and in many cases with business experience, in the period from May to June 2020, i.e., under the conditions of the COVID-19 pandemic. The crisis caused by the COVID-19 pandemic seems to change the environment even more, forcing companies to rebuild their business models and reformulate their place and role in society [12]. The study of students' attitudes and beliefs is all the more important because, as Jayakumar \& Joshi business schools suggest, through curricula that include ethical decision-making, ethical leadership, and corporate governance, they shape ethical business leaders who should understand business responsibility in society [13].

Our article has been organized as follows. First, by discussing the essence and nature of CSR, we identify the dimensions of social responsibility in which we are interested. Secondly, we refer to the relationship between social responsibility and crisis situations, including the COVID-19 pandemic. Thirdly, we present the characteristics of Generation Z, indicating their attitudes towards social responsibility. Fourthly, we describe Industry 4.0, pointing to management concepts which support the effectiveness of the implementation process. Fifthly, referring to the results of a critical review of the literature, we present the methodology and results of research. Finally, based on the results of the research, we conduct a discussion indicating the directions of changes in the significance of corporate social responsibility as a result of management solutions supporting Industry 4.0.

\section{Theoretical Background}

\subsection{Dimensions of Corporate Social Responsibility}

Despite the importance of social responsibility, which becomes a typical business activity, and is increasingly endorsed as a core area of management, alongside marketing, accounting and finance [14], the literature points to problems related to defining the essence and nature of CSR [15]. Aguilera et al. suggest that the problem for managers is to understand how CSR activities and strategies can affect financial and social performance [16]. These problems are related to the consequence of the diverse nature of enterprises and the corporation's focus on the environmental and social consequences of its activities [1] and arise from the evolution of both the concept itself and the needs of stakeholders [2]. Therefore, one shall agree with Van Marrewijk's suggestion that "one solution fits all" should be abandoned and that accepting various and more specific definitions matching the development, awareness and ambition levels of organizations should be accepted [17]. This ambiguity of CSR, combined with the complexity of the CSR construct, leads us to examine CSR not so much as a compact construct, but through the prism of its dimensions. Referencing the CSR dimensions that define the content of the structure allows for a fuller understanding of aspects of CSR use, and furthermore the interrelationships between these 
dimensions could clearly identify the drivers and dependent variables and the ways in which they are related to each other across various levels [14].

Although researchers conducting research in the area of social responsibility distinguish two [18], three [17,19], four [20,21], five [19], six (Sarkar \& Searcy 2016), nine [22] or even sixteen [14] dimensions, in our study we decided to narrow the dimensions of the analysis to three, assuming, as Aguinis, that organizational responsibility is defined as context-specific organizational actions and policies that take into account stakeholders' expectations and the triple bottom line of economic, social, and environmental performance [23]. In pointing out the rationale for limiting the scope of research to three dimensions, we also refer to the cultural context. The observations of Silva Junior et al. suggest that while in the USA the concept of CSR is directed towards philanthropic aspects, in Brazil towards reducing huge social inequalities, in Europe CSR pushes for the integration of economic, social and environmental issues into an organizational philosophy [24].

\subsection{Crisis and Corporate Social Responsibility}

The research has established connections between CSR and crises [25], although there is no clear consensus on the relationship between economic crises and social responsibility. Fehre \& Weber point out that in a global crisis, the fundamental principles of companies are eroded, destroying trust and leaving stakeholders confused and inclined to limit their involvement [26].

Souto suggests that CSR can be seen as a way of dealing with a crisis situation, helping companies to overcome the negative consequences of the crisis [27]. A similar conclusion is drawn by Seeger et al. who, while pointing out the positive aspects of crises, suggest that crises can provide a springboard for exploiting CSR opportunities. This is because they force companies to question basic assumptions, to renew themselves organizationally and strategically and above all to restore their image by redirecting efforts towards a socially responsible approach [28]. However, in times of crisis, company managers may feel pressure to give up CSR as an "unaffordable luxury". Bhattacharya et al. suggest that CSR can act as a calculated initiative to differentiate a company from its competitors, increasing the value of brands [29]. A similar conclusion is drawn by Coombs \& Holladay indicating that CSR can be considered to be a strategic tool for building a positive reputation [25], and by Klein and Dawar suggesting that CSR reduces the impact of adverse events such as product-harm crises [30], whereby reputable companies can go through crises with less economic loss than companies without a good reputation [31].

Similar arguments are raised by Ellouze suggesting that socially responsible firms are more likely to overcome crises and ensure a certain level of profitability, as the reputation of socially responsible acts as an insurance-like protection and provides a "reservoir of goodwill" in times of crises and economic turmoil [32]. Giannarakis \& Theotokas suggest that the benefits of CSR, which provides an opportunity to diversify products and services, may prove to be greater in times of crisis than in normal economic times [33]. Benlemlih \& Bitar and Mercadé-Melé et al., also point out that companies with a strong commitment to CSR achieve a high level of customer and stakeholder loyalty, attract high-quality employees, develop good relationships with market participants, build a good image and good reputation, and strengthen business in times of economic crisis [34,35].

Aguinis et al. suggest that CSR actions in response to COVID-19, although created by organizations, are implemented by individual employees, whose responses are key determinants of CSR implementation [36]. Fox et al. indicate that the COVID-19 pandemic represents a novel case of an unprecedented crisis because business leaders have no prior reference point to an event of this magnitude. At the same time, they suggest that true and genuine CSR in a pandemic can be an opportunity for development as it will strengthen the relationship between business, customers and the public [12]. 


\subsection{Generation $\mathrm{Z}$ and $\mathrm{CSR}$}

Generation $\mathrm{Z}$ represents the youngest cohort of workers, born in the digital age, who grow up during the technological explosion [37] and have never experienced a world without constant and ubiquitous connectivity [38]. Although Generation Z research is still in its infancy [39] it is suggested that its characteristics are in many respects similar to those of Generation Y [40,41]. However, other studies suggest that Generation Z has some important characteristics differentiating it from earlier generations: digital nativity; expectations of diversity; high level of pragmatism; high level of entrepreneurship; preference for personal communication [42], and a focus on cooperative, innovative, multitaskers and flourishes for instantaneous indulgence [43].

Ariker \& Toksoy, pointing out that while Generation $\mathrm{Z}$ has a positive attitude towards CSR activities, price, and quality are critical conditions in purchasing processes, while CSR issues appear to be secondary. At the same time, Ariker \& Toksoy suggest that Generation Z does not believe that companies implement CSR projects just due to their own interests but rather they have a win-win point of view [4]. In turn, Kim \& Austin, pointing out the strong commitment of the Millenniums and Generation Z to CSR, suggest that they are willing to support CSR by taking actions such as choosing brands to support their goals, expressing their views on the company's CSR activities, volunteering for a trusted company's goal, and are willing to pay extra for sustainable products and check packaging labels to make sure the product is socially sustainable [3]. Ying \& Kim suggest that Generation Z favors companies who are socially responsible and pay particular attention to social matters. They also point out that this generation responds positively to CSR initiatives when they receive the CSR efforts through an instrumental channel [44].

\subsection{Management Solutions Supporting Industry 4.0}

Trotta \& Garengo define Industry 4.0 as the integration of technology that allows the transformation of the way an organization operates with major changes in business models and production processes [45]. Similarly, the essence of Industry 4.0 is outlined by Bibby \& Dehe [46] indicating that Industry 4.0 represents the transformation of an organization in order to digitize the entire production process. Hermann et al. pointing to the value creation process assume that Industry 4.0 is an umbrella term for technologies and concepts of value chain organization [47]. Da Silva et al. extend the scope of the definition of Industry 4.0 by stating that it is a broad concept that encompasses a diversity of technologies, systems, and procedures, designed to make production processes more flexible, autonomous, dynamic and more precise [48]. In the subject literature, Industry 4.0 is also defined as strategy [49-51], paradigm [52-57] or concept [48,58-60]. Referring to the definition problems of Rosin et al., they indicate that although there was no consensus on the definition of Industry 4.0, a review of the literature indicates the words most frequently used in the definitions - communication, flexibility, and real time-which allows us to assume that Industry 4.0 is a way of implementing the principles of communication, flexibility, and real time [61]. The aim of Industry 4.0 is to achieve an advanced level of operational efficiency and productivity [62], and mass personalization of manufactured products using information technology, to achieve production optimization and to provide new types of services and business models for value chain interaction [63], which requires a high level of digitization and automation, broad communication in production environments and seamless integration of production systems [8].

Although the key features of Industry 4.0 suggest that in the process of implementation of Industry 4.0 the key success factor is meeting the relevant technological requirements and having the appropriate technologies-Internet of Things (IoT), Internet of Services (IoS), Big Data, Cloud Manufacturing, Cyber-Physical Systems (CPS), Augmented Reality, Radio Frequency Identification (RFID) [64] - it is worth paying attention to the links signaled in the literature between the effectiveness of implementation of Industry 4.0 and solutions from the area of management, suggesting that implementation of the assumptions of Industry 4.0 requires radical changes in business practices, leadership, decentralization of 
organizational structures, project management, process management $[48,65-67]$. Sony \& Naik, suggest that the lack of appropriate skills and support from management hinders the implementation of Industry 4.0 [11].

A similar position is presented by Da Silva et al., Suggesting that for the implementation of Industry 4.0, apart from technological requirements, also strategy, leadership, organizational culture, products and people are important [48]. Discussing Industry 4.0 maturity levels, Bibby \& Dehe pay attention to people and cultural aspects, influencing openness in data management, employees' ability to adopt new technologies, continuous improvement, innovation and communication [46]. Investigate Industry 4.0 and its enabling technologies Fatorachian \& Kazemi emphasize the role of flexibility in production processes, and also point to the importance of digitization and automation, and extensive connectivity in manufacturing environments [8]. Similar solutions are pointed out by Hamzeh et al., suggesting that the achievement of the Industry 4.0 goals require agility and flexibility in a production system and more agile production structures [68]. Also, Calabrese et al. relates to issues related to agility, competences or the design and management of complex systems [69]. Moeuf et al., pay attention to the issues of decentralization of information and decision-making in Industry 4.0, which is due to the fact that Industry 4.0 tools may require a large investment and a high level of expertise [66]. Schneider emphasizing that Industry 4.0 is challenging but promising field for management research raises issues related to decentralization, dispersion, flexibility, change of qualifications, network cooperation, change management and leadership [70].

Referring to the discussion in the subject literature we assumed that efficiency in the implementation process of Industry 4.0 can strengthen the use of: (a) remote and dispersed work [71]; (b) agile and shared leadership [70,72]; (c) decentralization [73]; (d) dynamic capabilities [74]; (f) agile management [75]; (g) process management [76]; (h) agile project management [77].

\section{Empirical Analysis}

Data Collection, Variables, and Method

The data presented in this study come from empirical surveys conducted as part of the research project called Directions of Changes in the Management of Companies within the COVID-19 Crisis. The main goal of the projects was to identify the perception of changes in the environment by students of economic faculties, allowing for the modification of curricula.

The data in the study were obtained from the students at the Nicolaus Copernicus University in Torun and the Poznan University of Economics. Both universities are among the best universities in Poland in the faculty of economic studies. The online questionnaire, which was made available to the respondents between May and June 2020, was completed by 646 students. Their characteristics are presented in Table 1 .

Table 1. Structure of the sample.

\begin{tabular}{lc}
\hline Characteristics & \% in Sample \\
\hline Year of studies & \\
1/I BSc & 22.0 \\
2/I BSc & 10.4 \\
1/II MSc & 16.6 \\
2/II MSc & 32.2 \\
3/II PhD & 18.9 \\
Faculty of studies & \\
Finance and accounting & 36.4 \\
Management & 50.3 \\
Economics & 13.3 \\
Gender & \\
female & 70.6 \\
male & 29.4 \\
\hline
\end{tabular}


Table 2 presents the description and scale of all analyzed variables.

Table 2. Description of variables.

\begin{tabular}{lcc}
\hline \multicolumn{1}{c}{ Description } & Label & Type \\
\hline $\begin{array}{l}\text { Explanatory variables } \\
\text { Remote and dispersed work } \\
\text { (virtualization) }\end{array}$ & $\mathrm{x}_{1}$ & Ordinal (1-7) \\
Agile and shared leadership & $\mathrm{x}_{2}$ & Ordinal (1-7) \\
Decentralization & $\mathrm{x}_{3}$ & Ordinal (1-7) \\
$\begin{array}{l}\text { Dynamic capabilities } \\
\text { Agile management }\end{array}$ & $\mathrm{x}_{4}$ & Ordinal (1-7) \\
Process management & $\mathrm{x}_{5}$ & Ordinal (1-7) \\
Agile project management & $\mathrm{x}_{6}$ & Ordinal (1-7) \\
Control variables & $\mathrm{x}_{7}$ & Ordinal (1-7) \\
Year of studies & & Ordinal (1-5) \\
Faculty_finance and & $\mathrm{x}_{8}$ & Dichotomous \\
accounting & $\mathrm{x}_{91}$ & Dichotomous \\
Faculty_management & $\mathrm{x}_{92}$ & Dichotomous \\
Gender (female) & $\mathrm{x}_{10}$ & \\
Explained variable & & Dichotomous \\
Increased importance of the & $\mathrm{y}_{1}$ & \\
social dimension of CSR & & Dichotomous \\
Increased importance of the & $\mathrm{y}_{2}$ & \\
environmental dimension of & & Dichotomous \\
CSR & $\mathrm{y}_{3}$ & \\
Increased importance of the & & \\
economic dimension of CSR & & \\
\hline
\end{tabular}

To study the effect of the explanatory variables on the dichotomous explanatory variable $y_{1}, y_{2}$, and $y_{3}$, a logit-based regression model has been used, which we can be written as:

$$
\log \text { it }\left(p_{i}\right)=Z_{i}=x_{i}^{\prime} \beta=\beta_{0}+\beta_{1} X_{1 i}+\beta_{2} X_{2 i}+\ldots+\beta_{k} X_{k i}
$$

where $\log$ it $\left(p_{i}\right)$ is marked as $\ln \frac{p_{i}}{1-p_{i}}$. The subject of estimation in this model are the $\beta_{0}, \beta_{1}, \beta_{2}, \ldots, \beta_{k}$ parameters which are the elements of the $\beta$ vector.

To estimate all the models, we used the maximum likelihood estimation method and the STATA.16.1 software (StataCorp. 2019. Stata Statistical Software: Release 16. College Station, TX: StataCorp LLC).

\section{Results and Discussion}

The results of the estimations are shown in Table 3.

The reliability tests carried out indicate the relevance of all models, which allows for further interpretation.

The results of the study suggest that the increase in the use of management solutions supporting Industry 4.0 as a result of the COVID-19 crisis will have an impact on the increase in importance of the economic, social, and environmental dimension of corporate social responsibility. Although the impact of management solutions supporting Industry 4.0 was indicated for all three dimensions, it is worth noting that the impact of individual solutions, except for agile project management, is limited to individual dimensions of corporate social responsibility. Thus, the results obtained indicate the correctness of the approach applied in research proceedings, based on a separate analysis of the dimensions of social responsibility, and not the construction of CSR treated as a coherent whole. At the same time, it is worth noting that although the strength of impact of individual management solutions supporting Industry 4.0 varies, no solutions have been identified in research 
proceedings, whose strength of impact on the increase in importance of CSR would be significantly higher than others.

Table 3. Logistic regression for $\mathrm{y}_{1}-\mathrm{y}_{3}$.

\begin{tabular}{|c|c|c|c|c|c|c|}
\hline Variables & $\mathbf{y}_{1}$ & & $\mathrm{y}_{2}$ & & $\mathbf{y}_{3}$ & \\
\hline & $\beta$ & OR & $\beta$ & OR & $\beta$ & OR \\
\hline $\mathrm{x}_{1}$ & 0.098 & 1.103 & -0.012 & 0.988 & 0.007 & 1.007 \\
\hline $\mathrm{x}_{2}$ & $0.173^{* *}$ & 1.189 & 0.029 & 1.029 & -0.013 & 0.987 \\
\hline$x_{3}$ & 0.054 & 1.056 & 0.128 * & 1.136 & 0.110 & 1.116 \\
\hline $\mathrm{x}_{4}$ & -0.024 & 0.976 & -0.046 & 0.955 & 0.055 & 1.056 \\
\hline$x_{5}$ & 0.052 & 1.053 & 0.009 & 1.009 & $0.171^{* *}$ & 1.186 \\
\hline$x_{6}$ & 0.054 & 1.056 & 0.076 & 1.079 & $0.248^{* * *}$ & 1.282 \\
\hline$x_{7}$ & 0.078 & 1.082 & 0.153 * & 1.165 & $0.139 *$ & 1.149 \\
\hline $\mathrm{x}_{8}$ & -0.103 & 0.902 & 0.008 & 1.008 & 0.062 & 1.064 \\
\hline $\mathrm{X}_{91}$ & $-0.496^{*}$ & 0.609 & -0.319 & 0.727 & -0.049 & 0.953 \\
\hline $\mathrm{X} 92$ & 0.042 & 1.043 & 0.087 & 1.091 & -0.093 & 0.912 \\
\hline $\mathrm{x}_{10}$ & -0.067 & 0.935 & 0.339 * & 1.403 & 0.203 & 1.226 \\
\hline constant & $-1.512^{* *}$ & 0.220 & $-2.265^{* * *}$ & 0.104 & $-3.226^{* * *}$ & 0.040 \\
\hline $\begin{array}{c}\text { Log } \\
\text { likelihood }\end{array}$ & -423.105 & & -413.04739 & & -395.53492 & \\
\hline $\begin{array}{l}\text { LR chi2 } \\
\text { (11) }\end{array}$ & 32.52 & & 27.36 & & 60.28 & \\
\hline Prob > chi2 & $0.0006^{* * *}$ & & $0.0041^{* * *}$ & & $0.0000^{* * *}$ & \\
\hline Pseudo R2 & 0.0370 & & 0.0321 & & 0.0708 & \\
\hline
\end{tabular}

*** $p$-Value $\leq 0.01 .{ }^{* *} p$-Value $\leq 0.05 .{ }^{*} p$-Value $\leq 0.1$.

Of the management solutions supporting Industry 4.0 analyzed in the research procedure, only the increase in the use of outsourcing and dynamic capacities will not translate into an increase in the importance of CSR in the aftermath of the COVID-19 crisis. If the impact of outsourcing is denied, the key issue seems to be to perceive it not so much in terms of a solution based on the use of resources available in the environment, but a mechanism for excluding part of the activity to the form of external entities. This perception of outsourcing, especially in the COVID-19 crisis, may be associated with layoffs and costcutting pressures that translate into reduced wage levels [78], and therefore not necessarily socially and economically fair [79], although it should be stressed that the results of studies on outsourcing suggest that outsourcing may be socially responsible [80]. In the context of the results obtained, it is puzzling that there are no identified links between dynamic capacities and CSR, which are often highlighted in the subject literature [81]. Dynamic capabilities, which are intra-organizational processes of integration, reconfiguration and acquisition/disposal of resources [82] affect the organization's flexibility and effectiveness in adapting to changes in the environment [83], and allow the organization to react quickly to changes in the needs of its stakeholders in crisis. This may be a consequence of the perception of COVID-19's impact in terms of a high level of impact intensity, albeit shortterm, while the underlying assumption for dynamic capabilities indicates their long-term impact [84]. Although the study has shown a lack of correlation between dynamic capabilities and CSR under COVID-19 conditions, it has not provided an attitude to formulate observations on the reasons for this, and we therefore consider it appropriate to deepen research in this area.

As regards the increased importance of the social dimension of CSR, the results of the study suggest the impact of agile and dispersed leadership. In times of crisis, the role of leaders who provide employees, through continuity of management processes, with a sense of certainty and stability, seems particularly important [85]. It is also worth noting that dispersed leadership has a positive impact on the increase of identification of employees with the organization [86] as well as on the improvement of communication processes with the environment [87], which improves relations with stakeholders and strengthens the legitimacy of the company [88]. 
Based on the results of the research, we suggest that the increased importance of the environmental dimension of social responsibility is supported by decentralization and agile project management. Decentralization, through mechanisms for transferring responsibility to lower levels of management, ensures that informational advantages can be gained and maintained [89], and has an impact on the speed of response to changes in the environment [90] and, as a result, on effectiveness of CSR [91]. Decentralization appears particularly relevant regarding the environmental dimension of CSR, as managers at lower levels of management, being more embedded in local environments, are better able to assess local conditions and requirements, which affects their level of environmental dimension of CSR. The agile project management iterative approach allows for effective management of ventures with a high level of under-determination [92], which in a highly volatile COVID19 environment seems to be crucial. Moreover, the concept of agile management, including agile project management, ensures greater reconfigurability of production systems, which in turn leads to higher environmental efficiency [93].

The impact of agile management, process management, and agile project management on the increase in importance of the economic dimension of CSR seems obvious. A high level of focus on customer expectations, as well as matching costs, quality, and time to the scope of the project provide better productivity, higher quality, and more efficient decision-making [94]. Moreover, the increase in the use of guilty management, process management and agile project management has a positive impact on employee involvement and empowerment [95], ensuring the development of their competences [96].

Taking into account the program of education in finance and accounting, one should rather expect, due to the pragmatic approach represented by students, negation of the economic dimension of CSR, while the results of the study suggest a negative impact of education in finance and accounting on the increase in importance of the social dimension of CSR in the aftermath of the COVID-19 crisis. The respondents' negation of the increase in importance of the social dimension of CSR in the aftermath of the COVID-19 crisis may result from doubts regarding the advisability of supporting external stakeholders, although verification of this observation requires in-depth research.

The positive impact of women in increasing the environmental dimension of CSR observed in the study is consistent with the results of Cucari, Esposito De Falco \& Orlando's research suggesting that women have a decisive role in environmental decision-making [97]. A similar conclusion is drawn by Hur, Kim \& Jang suggesting that women are more concerned about ethical issues, such as the environment, and are therefore more likely to engage in environmentally friendly behavior than men [98].

It is also worth noting that the study did not show a correlation between the year of study and the increase in importance of any of the dimensions of CSR analyzed. Similar conclusions regarding the lack of academic statute on the perception of CSR are drawn by Ugwuozor [99] and Teixeira et al. [100]. However, the research conducted on business students prepared by Haski-Leventhal et al. suggest that age influences positive evaluations of CSR attitudes [101]. It should be noted, however, that in their study, the respondents were people who belong to Generations X, Y, and Z, while we studied a homogenous generational cohort with very similar formative experiences.

\section{Conclusions}

The general image that emerges from the results of the study suggests that the increase in the use of management solutions supporting Industry 4.0 expected by the students of Generation $\mathrm{Z}$ will increase the importance of the economic, social, and environmental dimension of corporate social responsibility. It should be noted, however, that the individual dimensions of social responsibility under study are affected by various management solutions supporting Industry 4.0, moreover, only in the case of one management solution supporting Industry 4.0-agile project management-one can speak of its certain "universality". On the other hand, in the case of two management solutions supporting Industry 4.0 analyzed by us-outsourcing and dynamic capabilities-there are no grounds 
to conclude about their impact on the increase in importance of any of the CSR dimensions. It is also worth noting the negative impact, in the case of the social dimension, of education in finance and accounting, and the positive impact of gender (female) on the environmental dimension. Although in the case of the faculty and gender, the results of the study suggest the existence of specific dependencies, the year of study, which reflects the age and competence level of respondents, does not affect the increase in importance of the economic, social, and environmental dimension of corporate social responsibility, which seems to suggest that CSR awareness is inscribed in Generation Z's "DNA".

Our findings suggest that management solutions in support of Industry 4.0 are important for implementing the social responsibility of business. At the same time, referring to the opinions of students representing Generation Z, we suggest that the use of specific management solutions supporting Industry 4.0 has a positive impact on the effectiveness of the CSR implementation process. To our knowledge, the relationships identified by us between the implementation of CSR activities and process and product innovations have not been observed in earlier studies.

The results of our research have direct practical implications. Assuming that one of the important challenges facing enterprises is the integration of CSR into Industry 4.0, the study points, referring to the beliefs of Generation Z, to specific management solutions in support of Industry 4.0 that can be used to strengthen the role of CSR. Moreover, the results of research indicating the need for a stronger appreciation of specific management solutions supporting Industry 4.0 may be useful in the development of the digital transition strategy.

This study has certain limitations, which ensure that further studies can be carried out. First, respondents answered the questions within one month, with the majority completing the questionnaire in the first week after the launch of the survey, as a result of which it is difficult to draw conclusions relating, for example, to the reasons why the relationship between dynamic capabilities and CSR has not been observed in the COVID-19 conditions, as well as the denial by students in finance and accounting of the increased importance of the social dimension of CSR in the aftermath of the COVID-19 crisis. Therefore, we believe that to deepen conclusions, longitudinal studies should be used. Secondly, the research instrument that we have used, although it has allowed us to formulate important insights, needs to be refined. In particular, we believe that it would be useful to develop questions relating to the various dimensions of CSR. We also intend to include in our survey questions related to renewable energy. It seems that Generation Z, adopting the assumptions relating to sustainable development at a younger age than the previous generations, is characterized by a higher level of energy sensitivity. Further development and validation of the research instrument is an area on which future research should focus. The third limitation concerns the research sample. Although student respondents were appropriate for this study, particularly in the development of management solutions to support Industry 4.0, there is doubt about the possibility of generalizing the results of the study in different contexts. Respondents were recruited from among students of economic faculties, so their views may not be representative of all representatives of Generation $Z$. In future studies, we intend to broaden the population to include both students of non-economic faculties and non-students.

Author Contributions: Conceptualization, S.C., W.G. and M.Z.; methodology, S.C., W.G. and M.Z.; software, M.Z.; validation, M.Z.; formal analysis, S.C. and W.G.; investigation, S.C., W.G. and M.Z.; resources, M.Z.; data curation, M.Z.; writing-original draft preparation, S.C., W.G. and M.Z.; writing-review and editing, S.C., W.G. and M.Z.; visualization, W.G. and M.Z.; supervision, S.C. and M.Z.; project administration, W.G.; funding acquisition, W.G. All authors have read and agreed to the published version of the manuscript.

Funding: This research received no external funding.

Institutional Review Board Statement: Ethical review and approval were waived for this study. We informed participants that the survey is anonymous, we analyzed data anonymously and we did not ask about any personal information. 
Informed Consent Statement: Informed consent was obtained from all subjects involved in the study.

Data Availability Statement: Data is contained within the article.

Acknowledgments: This study was carried out as part of the project Directions of Changes in the Management of Companies in the COVID-19 crisis carried out under the NCBiR grant No. POWR.03.01.00-00-O001/17, entitled "Competences in process improvement with the use of ICT tools", implemented by the Nicolaus Copernicus University in Torun in the period: 01/09/201831/08/2021, under the Operational Program Knowledge Education Development (Priority axis: III. Higher education for economy and development; Action: 3.1. Competences in higher education). The authors would like to thank all students participating in the survey for their contribution in completing the questionnaire.

Conflicts of Interest: The authors declare no conflict of interest.

\section{References}

1. Zafar, M.B.; Sulaiman, A.A. Measuring corporate social responsibility in Islamic banking: What matters? Int. J. Islam. Middle East. Financ. Manag. 2020, 13, 357-388. [CrossRef]

2. Izzo, M.F.; Ciaburri, M. Why do they do that? Motives and dimensions of family firms' CSR engagement. Soc. Responsib. J. 2018, 14, 633-650. [CrossRef]

3. Kim, S.; Austin, L. Effects of CSR initiatives on company perceptions among Millennial and Gen Z consumers. Corp. Commun. 2019, 25, 299-317. [CrossRef]

4. Ariker, Ç.; Toksoy, A. Z jenerasyonu ve kss: Üniversite öğrencilerinin satin alma eğiliminin öncülleri. Kafkas Univ. Vet. Fak. Derg. 2017. [CrossRef]

5. Roman Pais Seles, B.M.; Lopes de Sousa Jabbour, A.B.; Chiappetta Jabbour, C.J.; Jugend, D. "In sickness and in health, in poverty and in wealth?": Economic crises and CSR change management in difficult times. J. Organ. Chang. Manag. 2018, 31, 4-25. [CrossRef]

6. Ghobakhloo, M. Industry 4.0, digitization, and opportunities for sustainability. J. Clean. Prod. 2020, 252, 119869. [CrossRef]

7. Akdil, K.Y.; Ustundag, A.; Cevikcan, E. Maturity and Readiness Model for Industry 4.0 Strategy. In Industry 4.0: Managing the Digital Transformation; Springer: Cham, Switzerland, 2018. [CrossRef]

8. Fatorachian, H.; Kazemi, H. A critical investigation of Industry 4.0 in manufacturing: Theoretical operationalisation framework. Prod. Plan. Control 2018, 29, 633-644. [CrossRef]

9. Scavarda, A.; Daú, G.; Scavarda, L.F.; Goyannes Gusmão Caiado, R. An Analysis of the Corporate Social Responsibility and the Industry 4.0 with Focus on the Youth Generation: A Sustainable Human Resource Management Framework. Sustainability 2019, 11, 5130. [CrossRef]

10. Knaut, A. How CSR Should Understand Digitalization. In Sustainability in a Digital World; Springer: Cham, Switzerland, 2017; pp. 249-256.

11. Sony, M.; Naik, S. Critical factors for the successful implementation of Industry 4.0: A review and future research direction. Prod. Plan. Control 2020, 31, 799-815. [CrossRef]

12. Fox, C.; Davis, P.; Baucus, M. Corporate social responsibility during unprecedented crises: The role of authentic leadership and business model flexibility. Manag. Decis. 2020, ahead-of-print. [CrossRef]

13. Jayakumar, T.; Joshi, R.K. Rethinking the role of management education in developing a "new" locus of CSR responsibility. J. Work. Manag. 2017, 9, 51-69. [CrossRef]

14. Alferaih, A. Understanding causal links among the dimensions of corporate social responsibility: A framework developed using interpretive structural modelling. Soc. Responsib. J. 2019, 16, 1357-1376. [CrossRef]

15. Sarkar, S.; Coelho, D.M.; Maroco, J. Strategic Orientations, Dynamic Capabilities, and Firm Performance: An Analysis for Knowledge Intensive Business Services. J. Knowl. Econ. 2016, 7, 1000-1020. [CrossRef]

16. Aguilera, R.V.; Rupp, D.E.; Williams, C.A.; Ganapathi, J. Putting the s back in corporate social responsibility: A multilevel theory of social change in organizations. Acad. Manag. Rev. 2007, 32, 836-863. [CrossRef]

17. Van Marrewijk, M. Concepts and Definitions of CSR and Corporate Sustainability: Between Agency and Communion. In Proceedings of the Journal of Business Ethics; Springer: Dordrecht, The Netherlands, 2003; Volume 44, pp. 95-105.

18. Hopkins, M. The Planetary Bargain; Palgrave Macmillan: London, UK, 1999.

19. Dahlsrud, A. How corporate social responsibility is defined: An analysis of 37 definitions. Corp. Soc. Responsib. Environ. Manag. 2008, 15, 1-13. [CrossRef]

20. Carroll, A.B. The pyramid of corporate social responsibility: Toward the moral management of organizational stakeholders. Bus. Horiz. 1991, 34, 39-48. [CrossRef]

21. Baden, D. A reconstruction of Carroll's pyramid of corporate social responsibility for the 21st century. Int. J. Corp. Soc. Responsib. 2016, 1, 8. [CrossRef]

22. Epstein, M.J. Making Sustainability Work; Routledge: Abingdon, UK, 2018. 
23. Aguinis, H. Organizational responsibility: Doing good and doing well. In APA Handbook of Industrial and Organizational Psychology, Vol 3: Maintaining, Expanding, and Contracting the Organization; American Psychological Association: Washington, DC, USA, 2010; pp. 855-879.

24. Da Silva Junior, A.; De Oliveira Martins-Silva, P.; Feu, K.S.; Komino, A.C.; Da Silva, V.C.; De Araújo Vasconcelos, K.C. Corporate social responsibility in the perspective of Brazilian management students: The inversion of the pyramid. Soc. Responsib. J. 2018, 16, 50-72. [CrossRef]

25. Coombs, T.; Holladay, S. CSR as crisis risk: Expanding how we conceptualize the relationship. Corp. Commun. 2015, 20, 144-162. [CrossRef]

26. Fehre, K.; Weber, F. Challenging corporate commitment to CSR: Do CEOs keep talking about corporate social responsibility (CSR) issues in times of the global financial crisis? Manag. Res. Rev. 2016, 39, 1410-1430. [CrossRef]

27. Souto, B.F.-F. Crisis and Corporate Social Responsibility: Threat or Opportunity? Int. J. Econ. Sci. Appl. Res. 2009, 2, 36-50.

28. Seeger, M.W.; Ulmer, R.R.; Novak, J.M.; Sellnow, T. Post-crisis discourse and organizational change, failure and renewal. J. Organ. Chang. Manag. 2005, 18, 78-95. [CrossRef]

29. Bhattacharya, A.; Good, V.; Sardashti, H. Doing good when times are bad: The impact of CSR on brands during recessions. Eur. J. Mark. 2020, 54, 2049-2077. [CrossRef]

30. Klein, J.; Dawar, N. Corporate social responsibility and consumers' attributions and brand evaluations in a product-harm crisis. Int. J. Res. Mark. 2004, 21, 203-217. [CrossRef]

31. Knight, R.F.; Pretty, D.J. Corporate Catastrophes, Stock Returns, and Trading Volume. Corp. Reput. Rev. 1999, 2, 363-378. [CrossRef]

32. Ellouze, D. The role of customers and employees in the buffer effect of corporate social responsibility in times of crisis. Manag. Financ. 2020, 46, 955-975. [CrossRef]

33. Giannarakis, G.; Theotokas, I. The Effect of Financial Crisis in Corporate Social Responsibility Performance. Int. J. Mark. Stud. 2011, 3, 2. [CrossRef]

34. Benlemlih, M.; Bitar, M. Corporate Social Responsibility and Investment Efficiency. J. Bus. Ethics 2018, 148, 647-671. [CrossRef]

35. Mercadé-Melé, P.; Molinillo, S.; Fernández-Morales, A.; Porcu, L. CSR activities and consumer loyalty: The effect of the type of publicizing medium. J. Bus. Econ. Manag. 2018, 19, 431-455. [CrossRef]

36. Aguinis, H.; Villamor, I.; Gabriel, K.P. Understanding employee responses to COVID-19: A behavioral corporate social responsibility perspective. Manag. Res. 2020, 18, 421-438. [CrossRef]

37. Turner, A. Generation Z: Technology and Social Interest. J. Individ. Psychol. 2015, 71, 103-113. [CrossRef]

38. Self, T.T.; Gordon, S.; Jolly, P.M. Talent management: A Delphi study of assessing and developing GenZ hospitality leaders. Int. J. Contemp. Hosp. Manag. 2019, 31, 4126-4149. [CrossRef]

39. Chillakuri, B. Understanding Generation Z expectations for effective onboarding. J. Organ. Chang. Manag. 2020. [CrossRef]

40. Mahmud, M.; Soetanto, D.; Jack, S. Environmental management and product innovation: The moderating role of the dynamic capability of small manufacturing firms. J. Clean. Prod. 2020, 264. [CrossRef]

41. Kim, M.; White, C.; Kim, C. Examining relationships among cultural factors and expectations of CSR. J. Commun. Manag. 2019, 23, 427-443. [CrossRef]

42. Lanier, K. 5 things HR professionals need to know about Generation Z. Strateg. HR Rev. 2017, 16, 288-290. [CrossRef]

43. Potluri, R.M.; Johnson, S.; Koppalakrishnan, P. An exploratory treatise on the ethnocentric tendencies of Emirati Gen Z consumers. J. Islam. Mark. 2020. [CrossRef]

44. Ying, L.C.; Kim, Y. Appealing to Young Consumers: An Examination of a Firm's CSR, CSR Communication, and Brand Attitudes of Generation Z. Acad. Asian Bus. Rev. 2018, 4, 25-56. [CrossRef]

45. Trotta, D.; Garengo, P. Industry 4.0 key research topics: A bibliometric review. In Proceedings of the 2018 7th International Conference on Industrial Technology and Management, ICITM 2018, Oxford, UK, 7-9 March 2018; Institute of Electrical and Electronics Engineers Inc.: Piscataway, NJ, USA, 2018; Volume 2018, pp. 113-117.

46. Bibby, L.; Dehe, B. Defining and assessing industry 4.0 maturity levels-Case of the defence sector. Prod. Plan. Control 2018, 29, 1030-1043. [CrossRef]

47. Hermann, M.; Pentek, T.; Otto, B. Design principles for industrie 4.0 scenarios. In Proceedings of the Annual Hawaii International Conference on System Sciences, Koloa, HI, USA, 5-8 January 2016; IEEE Computer Society: Washington, DC, USA, 2016; Volume 2016, pp. 3928-3937.

48. Da Silva, V.L.; Kovaleski, J.L.; Pagani, R.N.; Silva, J.D.M.; Corsi, A. Implementation of Industry 4.0 concept in companies: Empirical evidences. Int. J. Comput. Integr. Manuf. 2020, 33, 325-342. [CrossRef]

49. Shi, Z.; Xie, Y.; Xue, W.; Chen, Y.; Fu, L.; Xu, X. Smart factory in Industry 4.0. Syst. Res. Behav. Sci. 2020, 37, 607-617. [CrossRef]

50. Chiarini, A.; Belvedere, V.; Grando, A. Industry 4.0 strategies and technological developments. An exploratory research from Italian manufacturing companies. Prod. Plan. Control 2020, 31, 1385-1398. [CrossRef]

51. Mahdiraji, H.A.; Zavadskas, E.K.; Skare, M.; Kafshgar, F.Z.R.; Arab, A. Evaluating strategies for implementing industry 4.0: A hybrid expert oriented approach of BWM and interval valued intuitionistic fuzzy TODIM. Econ. Res. 2020, 33, 1600-1620. [CrossRef]

52. Ribeiro da Silva, E.H.D.; Shinohara, A.C.; Pinheiro de Lima, E.; Angelis, J.; Machado, C.G. Reviewing digital manufacturing concept in the Industry 4.0 paradigm. In Proceedings of the Procedia CIRP; Elsevier: Amsterdam, The Netherlands, 2019; Volume 81, pp. 240-245. 
53. Shamsie, J.; Martin, X.; Miller, D. In With The Old, In with The New: Capabilities, Strategies, And Performance Among The Hollywood Studios. Strateg. Manag. J. 2009, 30, 1440-1452. [CrossRef]

54. Mourtzis, D.; Zogopoulos, V.; Katagis, I.; Lagios, P. Augmented Reality based Visualization of CAM Instructions towards Industry 4.0 paradigm: A CNC Bending Machine case study. In Proceedings of the Procedia CIRP; Elsevier: Amsterdam, The Netherlands, 2018; Volume 70, pp. 368-373.

55. Ardanza, A.; Moreno, A.; Segura, Á.; De la Cruz, M.; Aguinaga, D. Sustainable and flexible industrial human machine interfaces to support adaptable applications in the Industry 4.0 paradigm. Int. J. Prod. Res. 2019, 57, 4045-4059. [CrossRef]

56. Pereira, T.; Barreto, L.; Amaral, A. Network and information security challenges within Industry 4.0 paradigm. Procedia Manuf. 2017, 13, 1253-1260. [CrossRef]

57. Meski, O.; Belkadi, F.; Laroche, F.; Furet, B. Towards a knowledge-based framework for digital chain monitoring within the industry 4.0 paradigm. In Proceedings of the Procedia CIRP; Elsevier: Amsterdam, The Netherlands, 2019; Volume 84, pp. 118-123.

58. Miśkiewicz, R.; Wolniak, R. Practical Application of the Industry 4.0 Concept in a Steel Company. Sustainability 2020, 12, 5776. [CrossRef]

59. Rojko, A. Industry 4.0 Concept: Background and Overview. Int. J. Interact. Mob. Technol. 2017, 11, 77-90. [CrossRef]

60. Cunha, T.P.; Méxas, M.P.; Cantareli da Silva, A.; Gonçalves Quelhas, O.L. Proposal guidelines to implement the concepts of industry 4.0 into information technology companies. TQM J. 2020, 32, 741-759. [CrossRef]

61. Rosin, F.; Forget, P.; Lamouri, S.; Pellerin, R. Impacts of Industry 4.0 technologies on Lean principles. Int. J. Prod. Res. 2020, 58, 1644-1661. [CrossRef]

62. Haseeb, M.; Hussain, H.I.; Ślusarczyk, B.; Jermsittiparsert, K. Industry 4.0: A Solution towards Technology Challenges of Sustainable Business Performance. Soc. Sci. 2019, 8, 154. [CrossRef]

63. Lu, Y. Industry 4.0: A survey on technologies, applications and open research issues. J. Ind. Inf. Integr. 2017, 6, 1-10. [CrossRef]

64. Wang, L.; Li, E.P.H.; Ding, X.S. Does deliberate learning lead to dynamic capability? The role of organizational schema for Kodak, 1993-2011. J. Strateg. Manag. 2018, 11, 52-80. [CrossRef]

65. Calabrese, A.; Levialdi Ghiron, N.; Tiburzi, L. 'Evolutions' and 'revolutions' in manufacturers' implementation of industry 4.0: A literature review, a multiple case study, and a conceptual framework. Prod. Plan. Control 2020. [CrossRef]

66. Moeuf, A.; Pellerin, R.; Lamouri, S.; Tamayo-Giraldo, S.; Barbaray, R. The industrial management of SMEs in the era of Industry 4.0. Int. J. Prod. Res. 2018, 56, 1118-1136. [CrossRef]

67. Snieška, V.; Navickas, V.; Havierniková, K.; Okręglicka, M.; Gajda, W. Technical, information and innovation risks of industry 4.0 in small and medium-sized enterprises-Case of Slovakia and Poland. J. Bus. Econ. Manag. 2020, 21, 1269-1284. [CrossRef]

68. Hamzeh, R.; Zhong, R.; Xu, X.W. A Survey Study on Industry 4.0 for New Zealand Manufacturing. In Proceedings of the Procedia Manufacturing; Elsevier: Amsterdam, The Netherlands, 2018; Volume 26, pp. 49-57.

69. Calabrese, A.; Dora, M.; Levialdi Ghiron, N.; Tiburzi, L. Industry's 4.0 transformation process: How to start, where to aim, what to be aware of. Prod. Plan. Control 2020. [CrossRef]

70. Schneider, P. Managerial challenges of Industry 4.0: An empirically backed research agenda for a nascent field. Rev. Manag. Sci. 2018, 12, 803-848. [CrossRef]

71. Robertson, D. Product development performance: Strategy, organization, and management in the world auto industry. J. Eng. Technol. Manag. 1992, 9, 87-89. [CrossRef]

72. Attar, M.; Abdul-Kareem, A. The Role of Agile Leadership in Organisational Agility. In Agile Business Leadership Methods for Industry 4.0; Emerald Publishing Limited: Bingley, UK, 2020; pp. 171-191.

73. Santos, C.; Mehrsai, A.; Barros, A.C.; Araújo, M.; Ares, E. Towards Industry 4.0: An overview of European strategic roadmaps. Procedia Manuf. 2017, 13, 972-979. [CrossRef]

74. Kyläheiko, K.; Maijanen, P. Industry 4.0. Transformation Challenge in Light of Dynamic Capabilities. In Technical, Economic and Societal Effects of Manufacturing 4.0; Springer: Berlin/Heidelberg, Germany, 2020; pp. 169-189.

75. Rocha, C.F.; Mamédio, D.F.; Quandt, C.O. Startups and the innovation ecosystem in Industry 4.0. Technol. Anal. Strateg. Manag. 2019, 31, 1474-1487. [CrossRef]

76. Oztemel, E.; Gursev, S. Literature review of Industry 4.0 and related technologies. J. Intell. Manuf. 2020, 31, 127-182. [CrossRef]

77. Veile, J.W.; Kiel, D.; Müller, J.M.; Voigt, K.I. Lessons learned from Industry 4.0 implementation in the German manufacturing industry. J. Manuf. Technol. Manag. 2019. [CrossRef]

78. Delmotte, J.; Sels, L. HR outsourcing: Threat or opportunity? Pers. Rev. 2008, 37, 543-563. [CrossRef]

79. Sinn, H.-W. The Dilemma of Globalisation: A German Perspective; La Documentation Française: Paris, France, 2004 ; Volume 100.

80. Tesfom, G.; Birch, N.J. Do offshore outsourcing firms in the USA use their investments on corporate social responsibility to alleviate negative attitudes toward offshore outsourcing? Soc. Responsib. J. 2008, 4, 428-438. [CrossRef]

81. Stekelorum, R.; Laguir, I.; Courrent, J.M.; Jaegler, A. Extending CSR in SMEs' upstream supply chains: A dynamic capabilities perspective. Supply Chain Forum 2018, 19, 231-249. [CrossRef]

82. Eisenhardt, K.M.; Martin, J.A. Dynamic capabilities: What are they? Strateg. Manag. J. 2000, 21, 1105-1121. [CrossRef]

83. Hermawati, A.; Gunawan, E. The implementation of dynamic capabilities for small and medium-sized enterprises in creating innovation. VINE J. Inf. Knowl. Manag. Syst. 2020. [CrossRef]

84. Winter, S.G. Understanding dynamic capabilities. Strateg. Manag. J. 2003, 24, 991-995. [CrossRef] 
85. Dirani, K.M.; Abadi, M.; Alizadeh, A.; Barhate, B.; Garza, R.C.; Gunasekara, N.; Ibrahim, G.; Majzun, Z. Leadership competencies and the essential role of human resource development in times of crisis: A response to Covid-19 pandemic. Hum. Resour. Dev. Int. 2020, 23, 380-394. [CrossRef]

86. Muethel, M.; Hoegl, M. Cultural and societal influences on shared leadership in globally dispersed teams. J. Int. Manag. 2010, 16, 234-246. [CrossRef]

87. Brown, M.E.; Gioia, D.A. Making things click. Distributive leadership in an online division of an offline organization. Leadersh. Q. 2002, 13, 397-419. [CrossRef]

88. Voegtlin, C.; Patzer, M.; Scherer, A.G. Responsible Leadership in Global Business: A New Approach to Leadership and Its Multi-Level Outcomes. J. Bus. Ethics 2012, 105, 1-16. [CrossRef]

89. Chia, Y.M. Decentralization, management accounting system (MAS) information characteristics and their interaction effects on managerial performance: A Singapore study. J. Bus. Financ. Account. 1995, 22, 811-830. [CrossRef]

90. Govindahajan, V. Decentralization, Strategy, and Effectiveness of Strategic Business Units in Multibusiness Organizations. Acad. Manag. Rev. 1986, 11, 844-856. [CrossRef]

91. Muller, A. Global Versus Local CSR Strategies. Eur. Manag. J. 2006, 24, 189-198. [CrossRef]

92. Conforto, E.C.; Amaral, D.C. Agile project management and stage-gate model-A hybrid framework for technology-based companies. J. Eng. Technol. Manag. 2016, 40,1-14. [CrossRef]

93. Dubey, R.; Gunasekaran, A.; Helo, P.; Papadopoulos, T.; Childe, S.J.; Sahay, B.S. Explaining the impact of reconfigurable manufacturing systems on environmental performance: The role of top management and organizational culture. J. Clean. Prod. 2017, 141, 56-66. [CrossRef]

94. Tsoy, M.; Staples, D.S. What Are the Critical Success Factors for Agile Analytics Projects? Inf. Syst. Manag. 2020, 1-18. [CrossRef]

95. Thompson, G.; Seymour, L.F.; O’Donovan, B. Towards a BPM success model: An analysis in South African financial services organisations. In Proceedings of the Lecture Notes in Business Information Processing; Springer: Berlin/Heidelberg, Germany, 2009; Volume 29, pp. 1-13.

96. Jin-Hai, L.; Anderson, A.R.; Harrison, R.T. The evolution of agile manufacturing. Bus. Process Manag. J. 2003, 9, 170-189. [CrossRef]

97. Cucari, N.; Esposito De Falco, S.; Orlando, B. Diversity of Board of Directors and Environmental Social Governance: Evidence from Italian Listed Companies. Corp. Soc. Responsib. Environ. Manag. 2018, 25, 250-266. [CrossRef]

98. Hur, W.-M.; Kim, H.; Jang, J.H. The Role of Gender Differences in the Impact of CSR Perceptions on Corporate Marketing Outcomes. Corp. Soc. Responsib. Environ. Manag. 2016, 23, 345-357. [CrossRef]

99. Ugwuozor, F.O. Students' perception of corporate social responsibility: Analyzing the influence of gender, academic status, and exposure to business ethics education. Bus. Ethics Eur. Rev. 2020, 29, 737-747. [CrossRef]

100. Teixeira, A.; Ferreira, M.R.; Correia, A.; Lima, V. Students' perceptions of corporate social responsibility: Evidences from a Portuguese higher education institution. Int. Rev. Public Nonprofit Mark. 2018, 15, 235-252. [CrossRef]

101. Haski-Leventhal, D.; Pournader, M.; McKinnon, A. The Role of Gender and Age in Business Students' Values, CSR Attitudes, and Responsible Management Education: Learnings from the PRME International Survey. J. Bus. Ethics 2017, 146, 219-239. [CrossRef] 